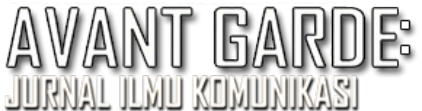

\title{
Strategi Media Relations Humas Kementerian Sosial Republik Indonesia Pada Program Prioritas
}

\author{
Dian Lestari, Meinati Fajar Rizki \\ e-mail:mei.prodihumas@gmail.com. \\ Universitas Negeri Jakarta. Indonesia
}

Submitted: 07 November 2019 Revised: 05 December 2019 Accepted: 19 December 2019

\begin{abstract}
Abstrak
Kementerian Sosial RI merupakan Instansi Pemerintah Berdasarkan Peraturan Presiden No. 46 Tahun 2015 tentang Kementerian Sosial, mempunyai tugas menyelenggarakan urusan di bidang rehabilitasi sosial, jaminan sosial, pemberdayaan sosial, perlindungan sosial, dan penanganan fakir miskin. Media relations dilakukan secara berkala namun banyak berita yang tidak diberitakan, seperti berita mengenai keberhasilan Program Prioritas yaitu Bantuan Pangan Non Tunai (BPNT) dan Program Keluarga Harapan (PKH). Tujuan dari penelitian ini untuk mengetahui bagaimana strategi media relations kementerian sosial untuk meningkatkan publisitas di media massa. Media relations merupakan bagian dari humas eksternal yang membina dan mengembangkan hubungan baik dengan media massa sebagai sarana komunikasi. Peneliti menggunakan teori Jefkins dari prinsip umum untuk membina hubungan media atau media relations yang baik. Penelitian ini menggunakan jenis penelitian deskriptif kualitatif, data diperoleh melalui pengumpulan data primer dan sekunder. Sedangkan subjek penelitian terdiri dari 1 key informan dan 3 informan. Berdasarkan hasil penelitian kemensos sudah menerapkan teori dari Frank Jefkins prinsip umum membina hubungan baik, namun dalam strategi yang dilakukan masih banyak kekurangan dan perlu ditingkatkan kembali. Dari ke 6 poin teori menurut jefkins, by serving the media, by establishing a reputations for reliability, by supplying good copy, by coorperations in providing material, by providing verifivation facilities, by building personal relationship with the media, Kemensos perlu penguatan media relations pada bagian by providing verifivation facilities dan by building personal relationship with the media. Agar media memberitakan info terkait dengan Kemensos RI dan program-program yang dijalankannya.
\end{abstract}

Kata kunci: Hubungan Masyarakat; Kemensos RI; Program Prioritas; Strategi Media Relations

\author{
Media Relations Strategy Public Relations Ministry of Social Affairs Republic of Indonesia \\ on Priority Programs
}

\begin{abstract}
The Ministry of Social Affairs of the Republic of Indonesia is a Government Agency Based on Presidential Regulation No. 46 of 2015 concerning the Ministry of Social Affairs, has the task of organizing affairs in the fields of social rehabilitation, social security, social empowerment, social protection, and handling of the poor. Media relations are conducted regularly but many news are not reported, such as news about the success of the Priority Program, namely Non-Cash Food Assistance (BPNT) and the Family Hope Program (PKH). The purpose of this study is to find out how the social ministry's media relations strategy is to increase publicity in the mass media. Media relations is part of external public relations that fosters and develops good relations with the mass media as a means of communication. Researchers use Frank Jefkins' theory of general principles to foster good media relations or media relations. This research uses descriptive qualitative research, data obtained through primary and secondary data collection. While the research subjects consisted of 1 key informant and 3 informants. Based on the results of research the Ministry of Social Affairs has applied the theory of Frank Jefkins the general principle of fostering good relations, but in the strategy carried out there are still many shortcomings and need to be improved again. From the 6 theoretical points according to Jefkins, by serving the media, by establishing a reputation for reliability, by supplying good copy, by providing
\end{abstract}


cooperation in providing material, by providing verification facilities, by building personal relationships with the media, the Ministry of Social Affairs needs to strengthen media relations in section by providing verifivation facilities, and by building personal relationships with the media. So that the media can report information related to the Indonesian Ministry of Social Affairs and the programs that it runs.

Keywords: Kemensos RI; Priority Program; Public Relations; Strategic of Media Relations

\section{PENDAHULUAN}

Kementerian Sosial Republik Indonesia merupakan Instansi Pemerintah Berdasarkan Peraturan Presiden No. 46 Tahun 2015 tentang Kementerian Sosial, dinyatakan bahwa Kementerian Sosial mempunyai tugas menyelenggarakan urusan di bidang rehabilitasi sosial, jaminan sosial, pemberdayaan sosial, perlindungan sosial, dan penanganan fakir miskin untuk membantu Presiden dalam menyelengarakan pemerintahan Negara dan inklusivitas. Program yang dilakukan oleh Kemensos dalam penanganan fakir miskin yakni program prioritas. Program ini merupakan program yang bersifat menyentuh langsung kepentingan publik, bersifat monumental, lintas urusan, berskala besar dan memiliki urgensi yang tinggi serta memberikan dampak luas pada masyarakat.

Kementerian Sosial mempunyai beberapa program prioritas, salah satu programnya adalah Bantuan Pangan Non Tunai (BPNT) dan Program Keluarga Harapan (PKH) yang bantuannya diberikan dalam bentuk kartu seperti pada gambar 1. Hal ini dilaksanakan dalam upaya pengentasan kemiskinan dan belum mampu memberikan dampak besar, sehingga tujuan dari pembangunan nasional terkait masalah pemerataan kesejahteraan masyarakat masih menjadi masalah berkepanjangan (Utomo, Hakim, Ribawanto, 2016). Oleh karena itu pemerintah meluncurkan program Program
Keluarga Harapan (PKH) untuk menanggulangi masalah kemiskinan.

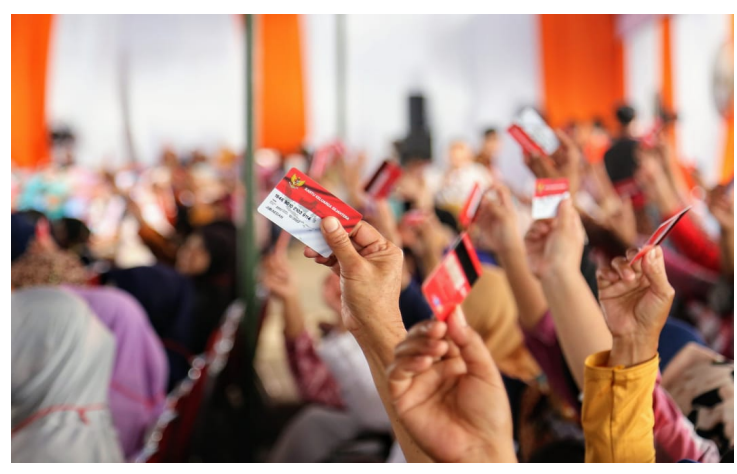

Sumber: Dokumentasi bagian Biro Humas Kementerian Sosial RI

\section{Gambar 1. FotoKartu BPNT dan PKH}

Program-program prioritas diberikan kepada masyarakat dengan cara penggunaan kartu BPNT dan PKH. Bantuan Pangan Non Tunai adalah bantuan pangan dari pemerintah yang diberikan kepada Keluarga Penerima Manfaat (KPM) setiap bulannya melalui mekanisme akun elektronik yang digunakan hanya untuk memberi pangan di e-Warong KUBE PKH/pedagang bahan pangan yang bekerja sama dengan Bank Himbara. BPNT bertujuan untuk mengurangi beban pengeluaran serta memberikan nutrisi yang lebih seimbang kepada KPM serta tepat sasaran dan tepat waktu dan mendorong pencapaian Tujuan Pembangunan Berkelanjutan (Sustainable Development Goals/SDGs).

Program Keluarga Harapan yang selanjutnya disebut PKH adalah program pemberian bantuan sosial bersyarat kepada Keluarga Penerima Manfaat (KPM) yang 
ditetapkan sebagai keluarga penerima manfaat PKH. Sebagai upaya percepatan penanggulangan kemiskinan, sejak tahun 2007 Pemerintah Indonesia telah melaksanakan PKH. Tujuan umum PKH adalah untuk meningkatkan aksesibilitas terhadap pelayanan pendidikan, kesehatan, dan kesejahteraan sosial dalam mendukung tercapainya kualitas hidup keluarga miskin. PKH diharapkan dapat mengurangi beban pengeluaran keluarga miskin dalam jangka pendek serta memutus rantai kemiskinan dalam jangka panjang. Dimana pemerintah memiliki peran yang besar dalam menyediakan santunan minimal agar masyarakat dapat mencapai kualitas hidup minimal (Suleman, Resnawaty, 2017).

Saat ini PKH merupakan program prioritas nasional yang mempunyai kemajuan yang sangat besar terhadap pengurangan kemiskinan dan kesenjangan pada tahun 2019. Namun informasinya masih sangat sedikit, sehingga banyak masyarakat yang tidak mengetahui program tersebut. Mulai dari pemberitaan media cetak, massa dan online, hanya ditemukan sedikit media yang mengangkat informasi tentang BPNT dan PKH. Informasi yang peneliti dapatkan dari salah satu media cetak menyatakan tidak semua informasi mengenai BPNT dan PKH itu diberitakan, terutama pada berita yang menginformasikan keberhasilan program tersebut. Informasi yang penulis terima dari reporter Republika cetak Rr. Laeny Sulistyawati Reporter Republika Cetak, pada Tanggal 1 Juli 2019, pukul 14:05, berikut kutipan wawancaranya: "Semua berita seperti besaran bantuan, penyaluran bantuan itu dipublikasikan. Tapi kalau berita keberhasilan atau sejenisnya itu tidak".
Pada kondisi inilah peran seorang humas harus dikuatkan, humas harus mencari solusi bagaimana caranya agar berita mengenai keberhasilan BPNT dan PKH dapat diketahui masyarakat. Public relations atau humas menurut Scott $\mathrm{M}$ Cutlip, Aleen H. Center dan Glen M. Broom pada dasarnya merupakan proses komunikasi kepada publik untuk menjalin relasi yang baik sehingga terjadi tujuan untuk membangun, membina dan menjaga citra yang positif atau reputasi baik (Iriantara, 2017). Membangun kerja sama dengan media merupakan salah satu cara untuk menyebarluaskan informasi mengenai PKH dan PBNT dalam menjalin hubungan baik antara pihak humas dan media.

Cutlip and Center menyatakan (Frisan Nova, 2017), "Good media relationship are earned trough honest helpful news service provided in an atmosphere of mutual respect and condor." (Hubungan media yang baik dapat diraih melalui kejujuran dan layanan media yang sangat membantu, yang dibangun dalam atmosfer saling terbuka dan hormat-menghormati satu sama lain). Media relations adalah salah satu cara untuk membuat citra menjadi baik. Kegiatan merujuk kepada bagaimana organisasi menggunakan media untuk mempengaruhi publik untuk mencapai tujuan organisasi. Seperti pada penelitian (Raharjo,2016) Media massa biasanya digunakan oleh perusahaan untuk membangun image perusahaan dan produk, tetapi juga perlu untuk membangun citra dengan melakukan penekanan pada manajemen Media relations.

Menurut Frank Jefkins (Rini Damarstuti, 2012) menguraikan beberapa 
prinsip umum untuk membina hubungan media atau media relations yang baik yaitu dengan (1) By serving the media (memahami dan melayani media), (2) By establishing a reputations for reliability (membangun reputasi sebagai orang yang dapat dipercaya), (3) By supplying good copy (menyediakan salinan yang baik), (4) By coorperations in providing material (bekerjasama dalam penyediaan materi), (5) By providing verifivation facilities (menyediakan fasilitas verifikasi), (6) $B y$ building personal relationship with the media (membangun hubungan personal yang kokoh). Peneliti akan menganalisis media relations yang terjalin pada humas kemensos dengan para awak media menggunakan teori frank jefkins.

Pada (Yuniarti, Primasari, 2013) penelitian Strategi Media Relations Humas Pemerintah Kota Bekasi dalam Upaya Penanganan Wartawan Tidak Resmi memiliki tujuan penelitian untuk menganalisis peran humas pemerintah kota Bekasi dalam upaya penanganan wartawan tidak resmi. Hasil Penelitian menunjukan bahwa hubungan baik yang dibina Humas Pemerintah Kota Bekasi dengan wartawan resmi secara tidak langsung telah menjauhkan gangguan dari wartawan tidak resmi. Kaitannya dengan penelitian ini adalah media relations sangat penting dijalin untuk penyebaran informasi. Adanya wartawan resmi dan tidak resmi juga menjadi salah satu hambatan informasi tidak tersebar dengan baik ke publik. Meskipun demikian media relations harus tetap dilakukan dengan memilah dan mencocokan data yang tepat yang diperuntukkan kepada wartawan resmi yang bekerja sama saja.

Penelitian lain berjudul aktivitas media relations humas setda kota Salatiga dalam membentuk berita positif (Pratiwi, Mayopu, Huwae, 2015) Jurnal ini terfokus pada aktivitas media relations informal yang lebih berperan dalam membentuk citra positif tentang pemerintahan kota salatiga di media cetak, karena mengedepankan hubungan personal antara humas dengan jurnalis. Keterkaitan dengan penelitian ini yaitu aktivitas media baik cetak maupun online tidak akan terpisah dari hubungan komunikasi antar jurnalis dengan humas. Humas melakukan media relations secara personal untuk membentuk citra positif. Melihat komunikasi antar pribadi di antara jurnalis dengan humas menjadi hal yang penting dalam membina media relations, demi terangkatnya berita perusahaan.

Media relations erat kaitannya dengan wartawan. Dalam penelitian Public Relations Hotel Grand Darmo Suite (Alim, 2016) divisi PR menjalin hubungan secara personal dengan wartawan media massa dan dengan institusi media massa, serta melakukan kegiatan media relations berupa mengirimkan press release dalam dua bahasa, yaitu bahasa Indonesia dan bahasa Inggris, mengadakan special event, wawancara pers, press luncheon dan melakukan media visit. Keterkaitan penelitian ini yaitu adanya hubungan yang dilakukan oleh pihak humas dalam menjalankan media relations ddari dua sisi. Yang pertama secara personal yang dilakukan personal kepada jurnalis, yang kedua hubungan baik kepada institusi media massa. Melihat effort yang dilakukan humas, berbeda dengan kegiatan humas lainnya yang hanya bertemu jurnalis pada saat acara di kantor saja. Hal ini menekankan kepada bagaimana kita dapat memanage relationship dengan 
semua publik termasuk jurnalis dan institusinya.

Peneliti berfokus pada strategi media relations dalam humas Pemerintah di Kemensos. Berdasarkan latar belakang masalah yang sudah diuraikan, maka peneliti merumuskan masalah sebagai berikut: "Bagaimana Strategi Media Relations Humas Kementerian Sosial RI pada Program Prioritas?". Sedangkan tujuan penelitian ini adalah untuk mengetahui Strategi Media Relations Humas Kementerian Sosial RI pada Program Prioritas Program Keluarga Harapan dan Bantuan Pangan Non Tunai dan untuk mengetahui hambatan humas dalam mempublikasikan Program Prioritas Keluarga Harapan dan Bantuan Pangan Non Tunai.

\section{METODE PENELITIAN}

Penelitian yang digunakan oleh peneliti adalah penelitian kualitatif. (Meleong, 2018) mendefinisikan metode kualitatif sebagai prosedur penelitian yang menghasilkan data deskriptif berupa katakata tertulis atau lisan dari orang-orang dan perilaku yang dapat diamati. Menurut mereka, pendekatan ini diarahkan pada latar dan individu tersebut secara holistik (utuh). Jadi dalam hal ini tidak boleh mengisolasikan individu atau organisasi ke dalam variabel atau hipotesis, tetapi perlu memandangnya sebagai bagian dari sesuatu keutuhan.

Jenis penelitian yaitu deskriptif, Secara harfiah metode deskriptif menurut (Bajari, 2017) adalah metode penelitian untuk membuat gambaran mengenai situasi atau kejadian, sehingga berkendak mengadakan akumulasi data dasar. Pada penelitian ini peneliti menggunakan jenis penelitian deskriptif karena jika data yang diperoleh dalam penelitian ini adalah berupa gambaran, gejala dan fenomena yang terjadi. Masalah yang terjadi yaitu informasi mengenai program di kementerian sosial tidak banyak diberitakan oleh media, sehingga masyarakat kurang yang mengetahui mengenai program tersebut.

Key informan yaitu mereka yang mengetahui dan memiliki berbagai informasi pokok yang diperlukan dalam penelitian (Sugiyono, 2010). Key informan pada penelitian ini yaitu Dr. Salahuddin Yahya, M.Si selaku Kepala Bagian Publikasi dan Pemberitaan Humas Kementerian Sosial R. Sedangkan informan adalah mereka yang memberikan informasi baik tentang dirinya ataupun orang lain atau suatu kejadian atau suatu hal kepada peneliti atau pewawancara mendalam (Afrizal, 2017). Informan pada penelitian ini yaitu Resti Aysiani Dewi selaku Kepala Sub.Bagian Pemberitaan, Alex Triono selaku Sesditjen Perlindungan dan Jaminan Sosial dan Rr. Laeny S selaku Journalist Republika.

Penelitian ini bertujuan untuk mendapat gambaran dan informasi yang lebih jelas, lengkap, serta memungkinkan dan mudah bagi penulis untuk melakukan penelitian observasi. Oleh karena itu, maka penulis menetapkan lokasi penelitian adalah tempat di mana penelitian akan dilakukan. Dalam hal ini, lokasi penelitian di Kementerian Sosial Republik Indonesia, yang terletak J1. Salemba Raya Nomor 28, RT.05/RW.06 Kenari, Kec Senen, Kota Jakarta Pusat, DKI Jakarta 40130. Penelitian ini dilakukan pada bulan Mei 2019 hingga bulan Juli 2019. Tehnik pengumpulan data yang digunakan dalam penelitian ini adalah wawancara mendalam 
dan observasi secara langsung pada biro humas Kemensos RI.

Pengumpulan data pada penelitian ini berasal dari dua sumber, yaitu: Data primer merupakan data utama yang diperoleh secara langsung di lapangan (Sugiyono, 2015). Metode pengumpulan data yang digunakan penulis untuk data primer adalah dengan melakukan wawancara langsung dan observasi. Dalam penelitian ini peneliti mendapatkan data primer dari tenaga kerja yang bekerja di Kementerian Sosial RI. Sedangkan data sekunder merupakan data yang digunakan untuk mendukung atau menunjang data primer sebagai literatur guna melengkapi data yang berhubungan dengan penelitian. Data sekunder berupa observasi yang telah didokumentasikan maupun berdasarkan wawancara dengan informan yang memiliki informasi tambahan serta sumber-sumber lainnya.

\section{HASIL DAN PEMBAHASAN}

Temuan utama dalam kegiatan media relations yang dilakukan oleh Humas Kemensos RI adalah tidak adanya timbal balik dari pihak wartawan untuk mengangkat berita terkait dengan program prioritas yang saat ini mulai terlihat keberhasilannya dalam menanggulangi kemiskinan. Humas sebagai komunikator Kemensos, sudah melakukan komunikasi dengan wartawan resmi dan media online yang tercatat bekerja sama dengan Kemensos. Humas Kementerian Sosial RI selalu melaksanakan kegiatan media relations agar hubungannya dengan media berjalan dengan baik. Namun sebelum kegiatan itu dilakukan, biasanya terlebih dulu melakukan proses implementasi di mana pertemuan ini bermaksud mencari bentuk tentang hal yang ingin disepakati dengan media agar menjadi relevan dengan isu-isu yang akan diangkat. Termasuk dengan informasi terkait program prioritas serta keberhasilan program PKH pada tahun ini.

Implementasi dilakukan oleh divisi humas untuk mengecek media mana saja yang sering melakukan peliputan serta mengangkat pemberitaan yang berhubungan dengan Kemensos. Setelah didapatkan data jurnalis tetap, jurnalis atau media tersebut akan masuk ke dalam forwasos. Forwasos (Forum Wartawan Sosial) adalah forum wartawan yang fokus memberitakan di bidang sosial dan diketuai oleh Sonya dari Kompas media cetak. Dibentuknya forwasos bertujuan untuk memudahkan wartawan dan membangun hubungan baik antara humas dengan media khususnya di Kemensos.

Hubungan yang subtantif juga diperkuat untuk dapat meningkatkan hubungan antara biro humas dengan media. Media yang diundang tentunya forwasos, namun humas kemensos juga memberikan kesempatan untuk mediamedia yang belum tergabung dalam forwasos. Setiap adanya kegiatan, humas melibatkan pimpinan yang ada pada jajaran Kemensos seperti dari Eselon 1 dan Direktur, dan itu tergantung dari isu apa yang sedang dibahas. Kegiatan ini merupakan salah satu upaya menjaga hubungan baik dengan wartawan. Kegiatan yang dirasa memiliki news value tinggi mengenai kebijakan baru atau keberhasilan program pasti diinfokan ke publik melalui konferensi pers yang sifatnya kondisional. Sedangkan press briefing diadakan 3 bulan sekali, dan press gathering satu tahun sekali.

Temuan lain pada kegiatan media relations di Kemensos yaitu dilakukannya 
profileling. Humas kemensos aktif melakukan profileling, yaitu suatu kegiatan untuk mengetahui kapan media tersebut ulang tahun, divisi humas akan mengirimkan karangan bunga dengan harapan supaya media tersebut dapat merasa diperhatikan dan juga untuk membuat hubungan dengan media semakin dekat. Komunikasi yang dilakukan oleh humas Kemensos juga dilakukan kepada instansi media. Selain itu juga dilakukan Millennials Group Discussion (MGD), yaitu pembentukan opini publik yang audiensnya para awak media dan jurnalis. MGD dilakukan ketika ada isu baru yang hangat di Kemensos, seperti program prioritas di beberapa daerah yang sudah mulai merata, dan beberapa daerah belum merata. Divisi humas memberikan data-data terkait dengan isu tersebut untuk didiskusikan oleh pihak media.

Tidak hanya hal tersebut, kegiatan media relations lainnya juga dilakukan oleh Humas Kemensos terkait dengan peliputan. Kegiatan ini dilakukan dengan cara mengundang wartawan untuk meliput kegiatan yang ada di Kemensos, untuk kegiatan program prioritas pihak Kemensos juga mengundang kegiatan di luar daerah, agar wartawan dapat meliput proses pemberitan bantuan dana, serta melihat langsung kondisi warga yang menerima bantuan PKH dan BPNT. Contohnya mengundang wartawan detik.com saat kegiatan PKH dan BPNT di Brebes dan wartawan Antara saat kegiatan PKH di Makasar. Liputan juga dilakukan di DKI Jakarta secara rutin yang bertujuan untuk mensosialisasikan informasi tentang program prioritas wilayah DKI Jakarta dan sekitarnya melalui media massa.
Pada setiap acara yang dilakukan ada beberapa fasilitas yang diberikan kepada para wartawan, seperti makanan, transport, dan fasilitas ruangan press room. Fasilitas yang diberikan kepada wartawan masih dalam tahap kecil dan ada pada anggaran untuk publikasi. Diinfokan oleh Kepala Sub. Bagian Pemberitaan Humas Kemensos bahwa:

“ Caranya, kita mengupayakan bagaimana mengemas isu yang ada di dalam BPNT dan PKH menjadi menarik untuk diangkat oleh media, sehingga kalau isunya menarik maka tidak harus membayar. Kemudian kalaupun kesulitan untuk pemberitaannya, kita lakukan penerapan dengan menggunakan anggaran publikasi namanya advertorial dan itu cukup mahal ya". (Resti Aysiani Dewi, Wawancara Data Primer, 28 Juni 2019).

Pernyataan di atas diperkuat juga oleh pertanyaan Kepala Humas Kemensos ketika menjelaskan hal terkait dengan pendanaan unttuk publikasi di media, pernyataannya sebagai berikut;

"Saya pikir hambatan memang ada, salah satu hambatannya untuk mengangkat pemberitaan itu secara masif, maksudnya baru mau mengangkat secara besar-besaran kalau dibangun hubungan kerja sama yang kontraktual dan itu membutuhkan pembiayaan yang lumayan besar, sementara kita mengelola anggaran dibandingkan dengan jumlah kebutuhan itu tidak berimbang". (Salahuddin Yahya, Wawancara Data Primer, 1 Juli 2019)

Adanya kepentingan uang dengan naiknya berita masih saling terkait dengan fakta yang ada di lapangan. (Adhianty, Wulan Frizky, 2015) Pada penelitian tersebut mengatakan bahwa masih ada 
perbedaan dalam menginterpretasikan

Kode Etik Jurnalis di kalangan wartawan.

Ada sebagian wartawan yang menganggap boleh menerima amplop karena sifatnya membantu biaya transportasi (bukan suap), dan asalkan tidak mempengaruhi pemberitaan. Humas seharusnya tidak menganggarkan dana amplop, karena hal ini mempengaruhi integritas wartawan dalam melakukan profesinya. Sehingga ketika Kemensos tidak membayarkan kepada media, berita tidak akan naik atau dipublish.

Hasil penelitian dan temuan di lapangan berhubungan dengan teori media relations dari Frank Jefkins (Rini Damarstuti, 2012). Teori ini menyebutkan bahwa prinsip umum untuk membina hubungan media atau media relations yang baik, yaitu by serving the media, by establishing a reputations for reliability, by supplying good copy, by coorperations in providing material, by providing verifivation facilities, by building personal relationship with the media untuk mengupas permasalahan yang terdapat pada hasil penelitian yang peneliti temukan dalam media relations Humas Kemensos.

(1) By serving the media. Strategi ini adalah strategi yang memberikan pelayanan kepada media. Salah satu pelayanan lain yang diberikan oleh humas kemensos dari analisa penulis yaitu dengan membentuknya Forum Wartawan Sosial atau biasa disebut dengan forwasos. Dibentuknya forwasos untuk memudahkan media dalam meliput berita dan dapat tepat sasaran media mana saja yang cocok untuk bekerja sama dalam pemberitaan dengan isu-isu yang terkait dengan program yang ada di Kemensos. Selain itu rekan media diberikan akses melakukan doorstop secara langsung kepada pimpinan. Doorstop merupakan salah satu wawancara dengan cara menghadang saat masuk atau meninggalkan acara. Hal ini dilakukan sebagai salah satu bentuk melayani media dari segi kebutuhan berita dan data melalui pembagian rilis dari divisi humas Kemensos RI. Serta kegiatan konferensi pers terkait dengan program prioritas seperti pada gambar 2.

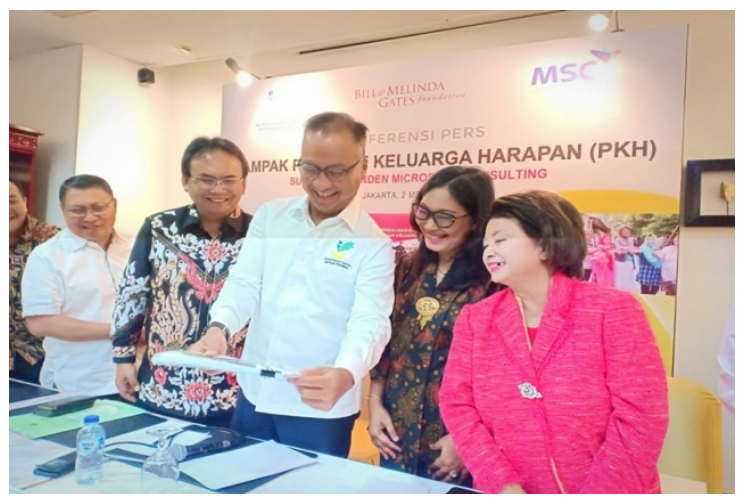

Sumber: Dokumentasi bagian Biro Humas Kementerian Sosial RI

\section{Gambar 2. Konferensi Pers Kemensos Program PKH}

(2) By establishing a reputations for reliability. Strategi ini yang dilakukan oleh public relations sebagai upaya menegakkan suatu reputasi agar dapat dipercaya. Strategi ini humas harus dapat dipercaya oleh media dengan melakukan kegiatan yang dapat meningkatkan reputasi Kemensos. Humas memberikan aksesibilitas yang lebih kepada pimpinan supaya adanya verifikasi data sehingga informasi yang dikeluarkan diharapkan akurat. Seperti kegiatan membuat tulisan yang dikirimkan ke media massa, seperti pemberitaan mengenai BPNT dan PKH. Jika ada penyaluran dan berapa besarannya akan diberitahu secara detail dan informasi yang diusahakan akurat. Apabila terjadi kesalahan dalam informasi tersebut, humas akan mengoreksinya kembali dan mengabarkan ke media. Biasanya data yang tidak akurat terjadi karena adanya perubahan yang mendadak 
pada saat peliputan. Seperti besaran mengenai penyaluran $\mathrm{PKH}$, data $\mathrm{PKH}$ memberikan bantuan 1500 KPM, tetapi di lapangan ternyata ada penambahan menjadi $1550 \mathrm{KPM}$. Hal itu sering sekali terjadi, oleh karena itu humas harus memperbarui data dengan unit yang bersangkutan jika ada penambahan atau pengurangan data. PKH sendiri dipegang oleh unit Perlindungan dan Jaminan Sosial. Jika ada kesalahan dari linjamsos, maka pihak linjamsos akan segera meberitahu biro humas, dan humas akan memperbaikinya sebelum diberikan kepada media. Berdasarkan penelitian yang telah dilakukan, humas Kemensos sudah melakukan hal yang dapat meningkatkan reputasi kemensos dengan cara memudahkan media mendapat aksesibilitas kepada pimpinan, sehingga informasi yang media dapat pasti sudah terverifikasi keakuratannya. Namun dalam hal ini terkadang dalam hal data terkadang sering kali menjadi sedikit bermasalah, bila data sudah naik ke media, namun perubahan dari dalam baru diinfokan. Sehingga keakuratan dan menjadi gatekeeper dalam mengeluarkan suatu informasi harus lebih diperhatikan oleh divisi humas.

(3) By supplying good copy Yaitu strategi dengan memasok naskah informasi yang baik. Humas kemensos sudah memberikan rilis yang tepat, baik dalam penulisan rilis ataupun dalam hal etika jurnalistiknya. Pernyataan itu disampaikan langsung oleh salah satu media yang menjadi informan peneliti. Meskipun sering kali media tersebut harus merevisi dahulu rilis yang diberikan. Press release yang diberikan oleh pihak Humas Kemensos selalu diberikan kepada media dengan tahapan pengecekan data dan info yang akurat. Sehingga dalam infonya dirasa sangat lama oleh pihak media.

(4) By coorperations in providing material adalah strategi yang dilakukan dengan kerja sama yang baik dalam menyediakan bahan informasi, yang menjadi penekanan dalam strategi ini adalah penghargaan yang tinggi dari seorang kepada media massa termasuk kepada pekerja media. Setiap masing-masing unit direktorat di Kemensos mempunyai Sub.Bagian Hubungan Masyarakat yang mempunyai tugas menyiapkan, dan mempublikasikan kemudian untuk pemberitaan.

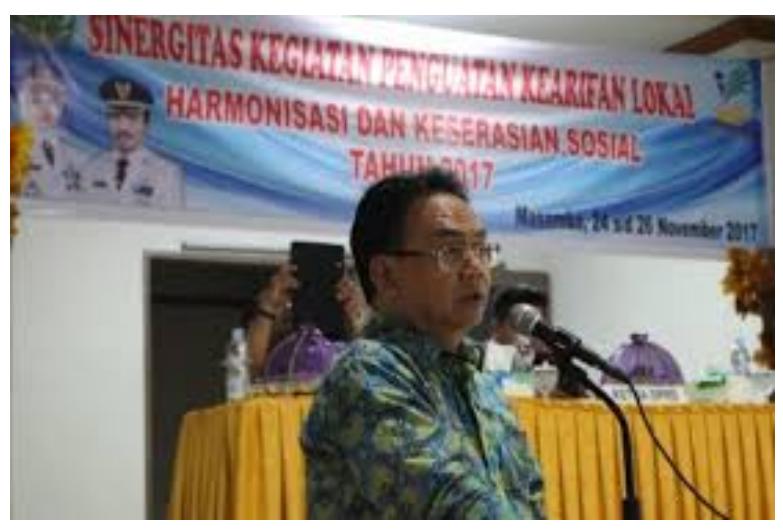

Sumber: Dokumentasi bagian Biro Humas Kementerian Sosial RI

\section{Gambar 3. Linjamsos Mendukung PKH}

Di unit Linjamsos sendiri Program PKH masuk ke dalam Jaminan Sosial Keluarga seperti pada gambar 3. Sub. Bagian humas Linjamsos juga mempunyai tenaga ahli media yang setiap saat selalu mempunyai berita, mereka membuat rilis. Setelah rilis sudah jadi lalu dikirimkan ke Sub.Bagian Pemberitaan yang ada di Biro Humas. Media dapat menghubungi humas bagian pemberitaan unduk mendapatkan informasi yang dibutuhkan. Jika informasi yang dibutukan langsung dapat dijawab, maka akan humas jawab mengenai informasi yang dibutuhkan. Namun, humas akan bertanya ke atas (pimpinan) atau unit yang bersangkutan jika informasi tersebut belum jelas, hal ini dilakukan untuk meminimalisir kesalahan informasi. 
(5) By providing verifivation facilities, Pada strategi ini seorang humas juga harus memikirkan fasilitas yang harus disediakan bagi pekerja-pekerja media. Tujuannya adalah pekerja media merasa nyaman dalam bekerja, yaitu ketika mereka melakukan liputan. Humas kemensos mempunyai cara untuk menerapkan strategi ini dengan memberikan fasilitas berupa sarana dan prasarana yaitu press room dan juga fasilitas internet yang dibutuhkan wartawan dalam meliput berita di kemensos. Namun, seperti yang dikatakan key informan, fasilitas ini kurang dimanfaatkan oleh wartawan ketika meliput. Oleh karena itu, humas akan merombak atau mendekor ulang ruangan agar nantinya press room dapat digunakan dengan nyaman.

(6) By building personal relationship with the media, Strategi keenam adalah by building personal relationship with the media merupakan strategi yang dilakukan dengan membangun hubungan secara personal antara public relations dengan media massa. Kegiatan yang dilakukan adalah media gathering, namun yang sering terjadi adalah sepinya pihak wartawan karena tidak ada pemberitaan penting. Selain itu pihak media yang diundang juga terbatas, biasanya media-media besar yang sudah terkenal, sedangkan media yang belum cukup dikenal namanya tidak diundang dalam acara gathering, namun pada acara lain media baru tetap diundang. Pelayanan lain yang humas kemensos lakukan adalah melakukan profiling kepada mediamedia yang aktif melakukan pemberitaan. Humas akan mengirimkan karangan bunga, apabila ada media yang sedang ulang tahun maka humas kemensos akan mengirimkan karangan bunga, dengan harapan supaya media tersebut merasa diperhatikan dan juga untuk membuat hubungan dengan media semakin dekat. Hubungan dengan media secara personal perlu ditingkatkan, karena pihak humas Kemensos hanya dekat dengan media besar yang memiliki banyak berita yang akan dipublish. Media-media di internet pun dapat mulai dijalin kerja sama, agar semakin meningkat pemberitaan perkait dengan program prioritas Kemensos RI.

Pada pemaparan di atas, dengan melihat kegiatan Humas Kemensos dalam menjalani media relations dengan para wartawan, Humas Kemensos menjalani fungsi setengah aktif dengan pers. Philip Lesley, penulis buku Public Relations Handbook mengemukakan fungsi humas dengan pers (Frisan Nova,2017) Fungsi setengah aktif yakni humas secara kontinyu humas mempersiapkan penyebaran info tentang berbagai kejadian di organissasi kepada berbagai media. Hal ini yang sudah dilakukan oleh Humas Kemensos dalam menjalani fungsinya untuk berhubungan dengan pers. Hubungan dijalin dengan melakukan berbagai macam hal, dan berbagai macam kegiatan yang menunjang media relations.

Humas Kemensos sudah melakukan kegiatan media relations sesuai dengan teori Frank Jefkins, walaupun di dalamnya masih terdapat kekurangan dan hambatan-hambatan. Dari ke-enam teori media relations yang dijalani oleh Humas kemensos, membuktikan bahwa menjalin hubungan yang baik dengan media serta jurnalis-jurnalisnya sangat penting agar berita yang berhubungan dengan Kemensos dapat dipublish. Forum Forwasos yang dibentuk dengan tujuan memudahkan wartawan untuk mendapatkan informasi terkait dengan Kemensos pun tidak dapat efektif 
memberitakan proses serta keberhasilan yang ada pada program prioritas.

Hambatan-hambatan juga terjadi terkait dengan semua informasi yang dimiliki oleh divisi humas, harus dilaporkan dulu ke jajaran petinggi kantor untuk selanjutnya mendapat approve atau tidak berita tersebut diberitakan ke publik. Untuk kegiatan media gathering yang menjadi ajang pendekatan secara personal kepada para jurnalis, juga masih dirasa terlalu memihak dengan wartawanwartawan dari media ternama saja. Padahal pembentukan forwasos bertujuan untuk merangkul media-media baru juga. Hal ini dirasa tidak sejalan oleh peneliti, karena media baru, akan lebih giat dan rajin menginformasikan berbagai macam berita. Tidak perfeksionis sifatnya, seperti yang dikatakan oleh wartawan senior yang sudah bekerja sama dengan Kemensos sejak lama, wartawan Republika. Bahwa kegiatan-kegiatan media gathering wartawan forwasos akan selalu hadir, namun tidak adanya perjanjian terikat bahwa berita harus dipublish, membuat para wartawan tidak mempublish berita yang diliput di Kemensos bila dianggap tidak menarik.

\section{SIMPULAN}

Simpulan dari Strategi Media Relations pada Humas Pemerintah dalam kegiatan media relations yang diterapkan Humas Kementerian Sosial RI berita mengenai BPNT dan PKH adalah dengan melakukan kegiatan Press release, Press Briefing, Press Profilling, Media Gathering, Press conference, Membentuk Forwasos (Forum Wartawan Sosial), dan Millennials Group Discussion (MGD). Dilihat dari ke enam strategi media relations yang telah dijalani, divisi Humas
Kemensos telah melakukan semua strategi sesuai dengan teori Frank Jefkins. Kemensos perlu penguatan media relations pada bagian by providing verifivation facilities dan by building personal relationship with the media. Pada bagian penguatan hubungan personal perlu dilakukan proses evaluasi kepada pihak media yang tergabung dalam forum Forwasos. Salah satu ketidaknyamanan yang diungkap oleh rekan wartawan adalah fasilitas press room yang kurang nyaman di Kemensos. Selain itu pada strategi building relationship, Humas Kemensos dapat melakukan pendekatan komunikasi personal.

Untuk meningkatkan efektivitas dan keberhasilan dari strategi media relations $d i$ Kementerian Sosial RI, peneliti menyampaikan berbagai saran yang diharapkan dapat membantu dan menjadi bahan pertimbangan untuk Kementerian Sosial RI. Adapun saransaran yang dapat peneliti berikan adalah sebagai berikut: (1) Mengembangkan kembali strategi media relations salah satu cara untuk meningkatkan hubungan yang baik sehingga dapat menghasilkan hubungan yang berkualitas. Hal ini terus dilakukan karena strategi yang dikembangkan dapat meningkatkan hubungan yang harmonis antara humas dengan media. (2) Untuk special event yang sudah direncanakan yaitu adanya award atau penghargaan untuk media yang aktif memberitakan di Kemensos diharapkan dapat terealisasikan tahun depan. Supaya media dapat merasa diperhatikan dan dapat menguatkan hubungan antara humas dan media. (3) Dalam hal publisitas, harus mempertahankan suatu publisitas positif, maka dari itu Humas Kemensos harus lebih aktif dalam memberikan informasi 
kepada wartawan, melakukan konfirmasi terhadap suatu berita, dan selalu menjaga hubungan baik dengan media. (4) Humas Kemensos dapat melakukan coffee morning atau coffee evening untuk mendekatkan diri dengan para jurnalis dan media, dengan mengangkat pembahasan umum yang tidak menitikberatkan kepada info-info Kemensos.

\section{UCAPAN TERIMA KASIH}

Puji dan syukur penulis panjatkan kepada Tuhan Yang Maha Esa atas berkah dan kelancaran yang diberikan sehingga penelitian yang berjudul "Strategi Media Relations Humas Kementerian Sosial Republik Indonesia Pada Program Prioritas" dapat selesai tepat pada waktunya. Selama proses penulisaan jurnal ini, banyak mendapatkan bantuan, bimbingan, dan dukungan baik secara moril maupun spiritual oleh karena itu ingin menyampaikan terima kasih kepada Kementerian Sosial Republik Indonesia yang telah bersedia untuk diwawancara menjelaskan info-info yang terkait untuk menunjang penelitian ini serta data-data yang diperlukan selama penelitian ini berlangsung. Akhir kata, penulis berharap karya ini dapat digunakan dan bermanfaat di kemudian hari untuk memperkaya jurnal seputar kegiatan media relations oleh Humas.

\section{DAFTAR PUSTAKA}

Afrizal. (2017). Metode Penelitian Kualitatif. Depok: PT Rajagrafindo Persada.

Alim, Anneke Lawrencia. (2016). Strategi Media Relations Hotel Grand Dammo Suite Surabaya Dalam Mengelola Publisitas Di Media Massa. Jurnal E-Komunikasi. Volume 4 Nomor 1. Halaman 1-11.
Bajari, Atwar. (2017). Metode Penelitian Komunikasi. Bandung: Simbiosa Retakama Media.

Darmastuti, Rini. (2012). Media Relations KonsepStrategi \& Aplikasi. Yogyakarta: Andi Offset.

Iriantara, Yosal. (2018). Media Relations Konsep Pendekatan dan Praktik. Bandung: PT. Remaja Rosdakarya.

Meleong, Lexy J. (2018). Metodologi Penelitian Kualitatif. Bandung: PT Remaja Rosdakarya Offset.

Nova, Frisan. (2017). CRISIS Public Relations. Depok: Rajawali Pers.

Nurjanah, Adhianty, Wulan Widyasari, Frizky Yulianti N. (2015). Public Relations Dan Media Relations (Kritik Budaya Amplop Pada Media Relations Institusi Pendidikan Di Yogyakarta. Jurnal Komunikasi. Volume 5 Nomor 1. Halaman 41-56.

Pratiwi, Nugrahaning Esa, Richard Gordon Mayopu, dan George Nicholas Huwae. (2015). Aktivitas Media Relations Humas Setda Kota Salatiga Dalam Membentuk Berita Positif. Jurnal Komunikasi ASPIKOM. Volume 5 Nomor 2. Halaman 330-345.

Raharjo, R., Sumantri. (2016). Media Relations Di Media Massa, Kegiatan Media Relations TVRI Yogyakarta Dan Jogja TV. Profetik Jurnal Komunikasi. Volume 9 Nomor 2. Halaman 5-14.

Sugiyono. (2010). Metode Penelitian Kuantitatif Kualitatif \& RND. Bandung : Alfabeta.

Sugiyono. (2015). Metode Penelitian Kuantitatif Kualitatif $R \& B$. Bandung: Aflabeta.

Suleman, Syahputra Adi Sanjaya, Risna Resnawaty. (2017). Program Keluarga Harapan (PKH): Antara Perlindungan Sosial Dan Pengentasan Kemiskinan. Prosiding Penelitian \& Pengabdian Kepada Masyarakat. Volume 4 Nomor 1. Halaman 1537. 
Utomo, Dedy, Abdul Hakim, Heru Ribawanto. (2016). Pelaksanaan Program Keluarga Harapan Dalam Meningkatkan Kualitas Hidup Rumah Tangga Miskin. Jurnal Administrasi Publik. Volume 2 Nomor 1. Halaman 29-34.

Yuniarti, Tatik \&Winda Primasari. (2013). Strategi Media Relations Humas Pemerintah Kota Bekasi dalam Upaya Penanganan Wartawan Tidak Resmi. Jurnal Universitas Islam "45" Bekasi. Journal Communication Spectrum. Volume 3 Nomor 2. Halaman 140-155. 